\title{
DRIS Norms and Sufficiency Ranges for Pepper Grown under Greenhouses Conditions in the Southeast of Spain
}

\author{
Alfonso Llanderal ${ }^{1,2,+}+\left(\mathbb{D}\right.$, Pedro García-Caparrós ${ }^{1,+}$, María Teresa Lao ${ }^{1,+}$ (D) and Maria Luz Segura ${ }^{3, *,+}$ \\ 1 Agronomy Department of Superior School Engineering, CIAIMBITAL, Agrifood Campus of International \\ Excellence ceiA3, University of Almeria, Ctra. Sacramento s/n, La Canada de San Urbano, 04120 Almería, \\ Spain; alfonsollanderal@hotmail.com (A.L.); pedrogar123@hotmail.com (P.G.-C.); mtlao@ual.es (M.T.L.) \\ 2 Faculty of Technical Education for Development, Catholic University of Santiago of Guayaquil, \\ Av. C. J. Arosemena Km. 1.5, Guayaquil 09014671, Ecuador \\ 3 Institute of Research and Training in Agriculture and Fishery (IFAPA), Junta of Andalusia, La Mojonera, \\ 04745 Almería, Spain \\ * Correspondence: marial.segura@juntadeandalucia.es \\ + The authors contributed equally to this work.
}

Citation: Llanderal, A.;

García-Caparrós, P.; Lao, M.T.;

Segura, M.L. DRIS Norms and

Sufficiency Ranges for Pepper Grown under Greenhouses Conditions in the Southeast of Spain. Agronomy 2021, 11, 837. https://doi.org/10.3390/ agronomy11050837

Academic Editor: Giuseppe Colla

Received: 5 April 2021

Accepted: 19 April 2021

Published: 24 April 2021

Publisher's Note: MDPI stays neutral with regard to jurisdictional claims in published maps and institutional affiliations.

Copyright: () 2021 by the authors. Licensee MDPI, Basel, Switzerland. This article is an open access article distributed under the terms and conditions of the Creative Commons Attribution (CC BY) license (https:// creativecommons.org/licenses/by/ $4.0 /)$.

\begin{abstract}
The aim of this study was to compile DRIS (Diagnosis and Recommendation Integrated System) norms and sufficiency ranges for pepper grown in greenhouses and the determination of the variation in DRIS norms and sufficiency ranges during the different phenological stages of the crop. The DRIS norms and sufficiency ranges were constituted by 367 leaf samples of Capsicum annuum L. which were collected in different phenological stages of the crop (flowering (FL), fruiting (FT), fruit development (FD), and harvesting (HV)). Two sufficiency ranges were developed; one including all leaf samples and the other considering the leaf samples by phenological stages ((FL) (44), (FT) (96), (FD) (100), and (HV) (127)). Furthermore, 10 DRIS norms and CV were calculated from N, P, K, Ca, and $\mathrm{Mg}$. Two ratios of them were calculated in FL (N/P and N/K), two in FD (N/P and Ca/N) and one in HV (N/P) showing low $C V$, meaning, according to DRIS norms, the essential role of these nutrients in the crop nutrition. Moreover, the sufficiency ranges computed by all database were: $\mathrm{N}$ (34-56), P (1.9-4.3), K (30-51), Ca (12-33), and $\mathrm{Mg}$ (4.0-15) ( $\left.\mathrm{mg} \mathrm{g}^{-1} \mathrm{DW}\right)$, respectively. The data obtained in this experiment highlighted the importance of the sensitivity (low CV) of nutrient in the phenological stages such as happened with $\mathrm{N}$.
\end{abstract}

Keywords: Capsicum annuum; Diagnosis and Recommendation Integrated System; Mediterranean climate; nutrient balance

\section{Introduction}

Currently, pepper is one of the most important crops together with tomato in greenhouses in Almeria. The statistical data noted that the total production in 2020 was of $845,727 \mathrm{t}$ for 11,936 ha reporting an income of EUR 659 million. Moreover, compared to 2019 , the production has increased by $7.7 \%$ highlighting the economic importance of this crop in the Southeast of Spain [1]. The most common varieties of peppers grown in Almeria are California, Lamuyo and Italian [2].

A higher yield is correlated with an adequate crop nutritional status and one of the most common methods to determine this parameter is through tissue analysis [3]. Besides the tissue analysis, another typical procedure to evaluate the nutritional status of one crop is based on the establishment of sufficiency ranges and DRIS norms $[4,5]$.

Nutrient sufficiency ranges are useful for diagnosing and correcting plant nutritional status in order to optimize yield and protect the environment [6]. Nevertheless, the tissue analysis used for the determination of nutrient sufficiency ranges are very sensitive to the plant's developmental stage, nutrient interactions, climate, and the part of the plant selected $[4,5,7]$. Moreover, if crops are mature, these comparisons are very difficult mainly 
due to the dilution of the nutrients in plants tissues [8]. In this sense, a feasible solution to establish the optimum foliar nutrient concentration ranges is the development of these sufficiency ranges according to the different phenological stages of the crop [5]. This methodology has also been reported in pepper crops by other researchers $[9,10]$.

One solution to solve this problem is the determination of DRIS (Diagnosis and Recommendation Integrated System) norms. Nevertheless, the DRIS norms can be also sensitive to different factors such as tissues age, phenological stage, climate, soil conditions, and the cultivar compared to the sufficiency range approach [11]. This low sensitivity can be ascribed to the determination of nutrient ratios as reported by Beaufils [12]. The DRIS norms consist of the mean, variance and coefficient of variation of the dual ratio between nutrients $(\mathrm{N} / \mathrm{P}, \mathrm{P} / \mathrm{N}, \mathrm{N} / \mathrm{K}, \mathrm{K} / \mathrm{N}$, etc.) obtained from a crop reference population that shows a high yield population [12].

The database to compose the DRIS norms is formed by the crop yield and chemical analysis of leaf tissue, and this information can be obtained from commercial crops or experimental units. The method to select the form of the ratio for a pair of nutrients to be used in DRIS calculation was described by Walworth and Sumner [13] and Nick [14]. DRIS evaluation has already been used and determined on pepper by El-Rheem et al. [15] and Sánchez et al. [11], but the information about the DRIS norms divided by phenological stages is rather scarce. Therefore, considering the importance of the pepper crop in the southeast of Spain, the aim of this study was to constitute DRIS norms and sufficiency ranges for pepper grown in greenhouses and the verification of the variation in DRIS norms and sufficiency ranges during the phenological stages.

\section{Materials and Methods}

The leaf tissue analysis of pepper was obtained from different experimental and commercial polyethylene greenhouses from 1984 to 1998 in the Southeast of Spain (Almería) in which they were grown during the season of autumn-winter in sandy mulching soils. This type of soil system is composed by sand mulching and artificial soil profile, which can be classified as a cumulic Anthrosol (variable texture varying from clay to sandy loam, high content of $\mathrm{CaCO}_{3}$ and a basic $\mathrm{pH}$ ) with an intermediate manure layer between both [4]. Sand mulching soil has been used by local growers to develop favorable conditions for the maintenance of horticultural crop growth in semiarid conditions [3].

The climatic parameters recorded from 1984 to 1998 (from July to April) in the outside of the greenhouse were acquired from the climatic weather station of the Institute of Research and Training in Agriculture and Fishery (IFAPA), Junta of Andalusia, La Mojonera, Almería. During the experimental period, the maximum and minimum temperature were 32 and $13{ }^{\circ} \mathrm{C}$, respectively. The maximum and minimum relative humidity ( $\mathrm{RH}$ ) over the experimental period were $84 \%$ and $41 \%$ and the global radiation ranged from 9 to $20 \mathrm{MJ} \mathrm{m}^{-2}$. All pepper crops were grown following the common indications given by local growers and researchers (planting density of 2 plants $\mathrm{m}^{-2}$ and fertigation with drippers of $\left.3 \mathrm{~L} \mathrm{~h}^{-1}\right)$.

Selection of references population. One of the most important factors to generate the DRIS norms is the reference population. The yield range of the reference population was around $7.24-9.12 \mathrm{~kg} \mathrm{~m}^{-2}$, being in line with the data reported by Valera et al. [2] who reported that a normal yield in pepper in this area is $6.94 \mathrm{~kg} \mathrm{~m}^{-2}$. The differences of the yield range of the reference group were related to the pepper crop cycle. The reference group showed a normal distribution as it has been reported by other researchers such as Walworth and Sumner [13].

Database. The database was constituted by 367 leaf samples of Capsicum annuum L. type California (cultivars Mazurca, California and Latino) and type Lamuyo (cultivars Clovis, Drago and Heldor) with growth cycles from July to April which were collected in different phenological stages of the crop flowering (FL) (August-September) (44), fruiting (FT) (96) (September-October), fruit development (FD) (September-October) (100), and harvesting (HV) (127) (from November to April). The nutrient solution supplied (mM) to 
grow the crop ranged from 8 to 17 for N, 0 to 4 for $\mathrm{P}, 6$ to 11 for $\mathrm{K}, 1$ to 3 for $\mathrm{Ca}$. There were no supplies of $\mathrm{Mg}$ in the nutrient solution due to the high concentration of this nutrient in the water chemical composition of this area. Moreover, it is necessary to point out that the level of organic matter in the soils ranged from 0.5 to $3 \%$.

Each leaf sample was composed by mixing 30-40 healthy and fully developed leaves (one leaf per plant) randomly chosen in the greenhouse. After leaf sample collection, they were washed, and the petioles were removed. Then, these samples were oven dried at $70^{\circ} \mathrm{C}$ until constant weight was attained. After this step, dried leaf samples were milled and sifted through an $80 \mu \mathrm{m}$ mesh sieve [16]. Lastly, they were preserved in airtight polyvinyl chloride (PVC) containers sealed with paraffin and stored in a dry place under darkness [17]. Each sample was divided into two subsamples; one was mineralized by the dry way method and used to determine total $\mathrm{P}$ concentration by the phosphovanadomolybdate method, and total potassium $(\mathrm{K})$, calcium $(\mathrm{Ca})$, and magnesium $(\mathrm{Mg})$ concentration were determined by atomic absorption spectrometry [17]. The other subsample was used to directly determine total $\mathrm{N}$ by the Kjeldahl digestion procedure [18].

Development of DRIS Norms. The determination of the " $R$ value" proposed by Nick [14] was used to select the ratio order of nutrients. This determination consisted in the calculation of the correlation coefficient (r) among the yield values recorded during the study along with the relationships between the pairs of nutrients in harvesting, either in direct or inverse order. The selection of the order of the relationship between pair of nutrients was based in the highest value of the coefficient of correlation (r):

$$
\begin{aligned}
& \text { If: } \mathrm{r} A / \mathrm{B}>\mathrm{rB} / \mathrm{A} \text { then: relationship in the norm }=\mathrm{A} / \mathrm{B} \\
& \text { If: } \mathrm{r} \mathrm{A} / \mathrm{B}<\mathrm{rB} / \mathrm{A} \text { then: relationship in the norm }=\mathrm{B} / \mathrm{A}
\end{aligned}
$$

where: $|\mathrm{r} A / \mathrm{B}|$ is the absolute value of the correlation coefficient between productivity, and $\mathrm{A} / \mathrm{B}$ is the ratio among the concentrations of the nutrients $\mathrm{A}$ and $\mathrm{B}$ of the population; $|\mathrm{r} B / \mathrm{A}|$ and $\mathrm{B} / \mathrm{A}$ are the same as above for nutrients $\mathrm{B}$ and $\mathrm{A}$ in inverse order. In the selection of the ratio order only the database of harvesting was used.

Sufficiency ranges. The optimum leaf range of each nutrient in pepper plants was determined using the DRIS technique. In fact, DRIS norms use the average value of each element obtained from the mineral composition of leaf tissues of the reference population as a reference value, thus establishing the sufficiency average. The optimum ranges are the values obtained from the average $\pm 4 / 3$ of standard deviation (SD) of the reference population $[19,20]$. With the data obtained, two sufficiency ranges were developed: one including all the database and the other was determined only according to the phenological stage.

Statistical analysis. The analysis of variance and the least significant difference tests $(p<0.05)$ were used to assess the differences between phenological stages. All statistical analyses were performed using Statgraphics Plus for Windows (version 5.1; Statpoint Technologies, Warrenton, VA, USA).

\section{Results}

The means macronutrients ratios and the $\mathrm{CV}$ of the population, and the correlation coefficients with the yield in harvesting are shown in the Table 1. Considering the following characterization according to the value of CV (\%): lower CV (15 to 30\%), moderate CV (31 to $45 \%)$, high CV (46 to $60 \%)$ and very high CV $(>60 \%)$, we can highlight that there was one ratio with low $\mathrm{CV}(\mathrm{N} / \mathrm{P})$, five ratios with a moderate $\mathrm{CV}(\mathrm{N} / \mathrm{K}, \mathrm{P} / \mathrm{K}, \mathrm{Ca} / \mathrm{N}, \mathrm{Ca} / \mathrm{Mg}$, $\mathrm{Mg} / \mathrm{N}$ and $\mathrm{Mg} / \mathrm{P})$, one ratio with high $\mathrm{CV}(\mathrm{P} / \mathrm{Ca})$, and two ratios with very high $\mathrm{CV}$ $(\mathrm{Ca} / \mathrm{K}$ and $\mathrm{Mg} / \mathrm{K})$. It is worth noting that the majority of the coefficients of correlation $(\mathrm{r})$ of the nutrients ratio showed a lower relationship with the yield (ranging from 0.24 to 0.38 ), unless for the $\mathrm{N} / \mathrm{P}$ and $\mathrm{Ca} / \mathrm{Mg}$ correlation which showed a negative moderated values $(-0.44$ and -0.27 , respectively). 
Table 1. DRIS norms (mean, CV, and correlation coefficient) in pepper crop in harvesting.

\begin{tabular}{cccc}
\hline Norms & Mean & CV (\%) & r \\
\hline $\mathrm{N} / \mathrm{P}$ & 13.44 & 23.58 & $-0.44^{*}$ \\
\hline $\mathrm{N} / \mathrm{K}$ & 1.23 & 41.40 & $0.31^{*}$ \\
\hline $\mathrm{P} / \mathrm{K}$ & 0.09 & 41.48 & $0.33^{*}$ \\
\hline $\mathrm{P} / \mathrm{Ca}$ & 0.11 & 57.02 & $0.28^{*}$ \\
\hline $\mathrm{Ca} / \mathrm{N}$ & 0.84 & 36.28 & $0.322^{*}$ \\
\hline $\mathrm{Ca} / \mathrm{K}$ & 1.10 & 68.22 & $0.24^{*}$ \\
\hline $\mathrm{Ca} / \mathrm{Mg}$ & 2.37 & 31.05 & $-0.27^{*}$ \\
\hline $\mathrm{Mg} / \mathrm{N}$ & 0.37 & 35.01 & $0.38^{*}$ \\
\hline $\mathrm{Mg} / \mathrm{P}$ & 4.95 & 41.79 & $0.29^{*}$ \\
\hline $\mathrm{Mg} / \mathrm{K}$ & 0.47 & 64.41 & $0.28^{*}$ \\
\hline
\end{tabular}

* indicates significant differences at $p<0.05$.

Comparing the different phonological stages of the pepper plant, there were significant differences in all ratios except for $\mathrm{N} / \mathrm{K}$ and $\mathrm{P} / \mathrm{K}$ which remained constant along the different phenological stages of the crop (Table 2). It is necessary to point out that the value of CV in the different phenological stages ranged from 19.22 to $44.12 \%$ in flowering (FL), 31.57 to $50.62 \%$ in fruiting (FT), 24.85 to $55.26 \%$ in fruit development (FD), and 23.58 to $68.22 \%$ harvesting $(\mathrm{HV})$. In the stage of flowering $(\mathrm{FL})$, there were two ratios with low $\mathrm{CV}$ $(\mathrm{N} / \mathrm{P}$ and $\mathrm{N} / \mathrm{K})$, eight ratios with moderate $\mathrm{CV}(\mathrm{P} / \mathrm{K}, \mathrm{P} / \mathrm{Ca}, \mathrm{Ca} / \mathrm{N}, \mathrm{Ca} / \mathrm{K}, \mathrm{Ca} / \mathrm{Mg}, \mathrm{Mg} / \mathrm{N}$, $\mathrm{Mg} / \mathrm{P}$, and $\mathrm{Mg} / \mathrm{K})$. In the stage of fruiting (FT), there were seven ratios with a moderate $\mathrm{CV}(\mathrm{N} / \mathrm{P}, \mathrm{N} / \mathrm{K}, \mathrm{P} / \mathrm{K}, \mathrm{Ca} / \mathrm{N}, \mathrm{Ca} / \mathrm{K}, \mathrm{Ca} / \mathrm{Mg}$, and $\mathrm{Mg} / \mathrm{N})$ and three ratios with high $\mathrm{CV}$ $(\mathrm{P} / \mathrm{Ca}, \mathrm{Mg} / \mathrm{P}$ and $\mathrm{Mg} / \mathrm{K})$. In the stage of fruit development (FD), there were two low $\mathrm{CV}$ $(\mathrm{N} / \mathrm{P}$ and $\mathrm{Ca} / \mathrm{N})$, five ratios with moderate $\mathrm{CV}(\mathrm{N} / \mathrm{K}, \mathrm{P} / \mathrm{Ca}, \mathrm{Ca} / \mathrm{K}, \mathrm{Ca} / \mathrm{Mg}$, and $\mathrm{Mg} / \mathrm{N})$ and three ratios with high $\mathrm{CV}(\mathrm{P} / \mathrm{K}, \mathrm{Mg} / \mathrm{P}$, and $\mathrm{Mg} / \mathrm{K})$. In the stage of harvesting $(\mathrm{HV})$, there was one ratio with low $C V(N / P)$, six ratios with moderate $\mathrm{CV}(\mathrm{N} / \mathrm{K}, \mathrm{P} / \mathrm{K}, \mathrm{Ca} / \mathrm{N}$, $\mathrm{Ca} / \mathrm{Mg}, \mathrm{Mg} / \mathrm{N}$, and $\mathrm{Mg} / \mathrm{P}$ ) and two ratios with high $\mathrm{CV}(\mathrm{Ca} / \mathrm{K}$ and $\mathrm{Mg} / \mathrm{K})$.

Table 2. Diagnosis and recommendation integrated system norms in different phenological stages of pepper crop. Means with different letters in the same row indicate significant differences between the different phenological stages. Flowering (FL), fruiting (FT), fruit development (FD), and harvesting (HV).

\begin{tabular}{ccccccccc}
\hline & \multicolumn{2}{c}{ FL } & \multicolumn{2}{c}{ FT } & \multicolumn{2}{c}{ FD } & \multicolumn{2}{c}{ HV } \\
\hline Norms & Mean & CV (\%) & Mean & CV (\%) & Mean & CV (\%) & Mean & CV (\%) \\
\hline $\mathrm{N} / \mathrm{P}$ & $17.78 \mathrm{a}$ & 26.44 & $15.29 \mathrm{~b}$ & 36.30 & $18.20 \mathrm{a}$ & 30.34 & $13.44 \mathrm{c}$ & 23.58 \\
\hline $\mathrm{N} / \mathrm{K}$ & $1.23 \mathrm{a}$ & 19.22 & $1.21 \mathrm{a}$ & 37.14 & $1.30 \mathrm{a}$ & 33.97 & $1.23 \mathrm{a}$ & 41.40 \\
\hline $\mathrm{P} / \mathrm{K}$ & $0.07 \mathrm{a}$ & 33.51 & $0.09 \mathrm{a}$ & 40.34 & $0.08 \mathrm{a}$ & 53.74 & $0.09 \mathrm{a}$ & 41.48 \\
\hline $\mathrm{P} / \mathrm{Ca}$ & $0.27 \mathrm{a}$ & 44.12 & $0.29 \mathrm{a}$ & 49.13 & $0.17 \mathrm{~b}$ & 38.76 & $0.11 \mathrm{c}$ & 57.02 \\
\hline $\mathrm{Ca} / \mathrm{N}$ & $0.26 \mathrm{c}$ & 32.67 & $0.28 \mathrm{c}$ & 34.59 & $0.37 \mathrm{~b}$ & 24.85 & $0.84 \mathrm{a}$ & 36.28 \\
\hline $\mathrm{Ca} / \mathrm{K}$ & $0.32 \mathrm{c}$ & 33.82 & $0.33 \mathrm{c}$ & 42.31 & $0.47 \mathrm{~b}$ & 36.30 & $1.10 \mathrm{a}$ & 68.22 \\
\hline $\mathrm{Ca} / \mathrm{Mg}$ & $2.14 \mathrm{a}$ & 38.16 & $1.79 \mathrm{~b}$ & 32.11 & $2.20 \mathrm{a}$ & 39.53 & $2.37 \mathrm{a}$ & 31.05 \\
\hline $\mathrm{Mg} / \mathrm{N}$ & $0.13 \mathrm{c}$ & 34.15 & $0.16 \mathrm{cb}$ & 31.57 & $0.18 \mathrm{~b}$ & 31.57 & $0.37 \mathrm{a}$ & 35.01 \\
\hline $\mathrm{Mg} / \mathrm{P}$ & $2.36 \mathrm{c}$ & 44.90 & $2.49 \mathrm{c}$ & 48.33 & $3.32 \mathrm{~b}$ & 45.64 & $4.95 \mathrm{a}$ & 41.79 \\
\hline $\mathrm{Mg} / \mathrm{K}$ & $0.16 \mathrm{c}$ & 35.20 & $0.20 \mathrm{cb}$ & 50.62 & $0.24 \mathrm{~b}$ & 55.26 & $0.47 \mathrm{a}$ & 64.41 \\
\hline
\end{tabular}

General sufficiency ranges for all the growing stages of pepper plants derived from DRIS norms using the complete data bank are shown in Table 3. The sufficiency ranges 
obtained in this survey were N (34-56), P (1.9-4.3), K (30-51), Ca (12-33), and Mg (4.0-15) $\left(\mathrm{mg} \mathrm{g}^{-1} \mathrm{DW}\right)$, respectively. All the nutrients showed normal distribution, therefore, these sufficiency ranges represented $80 \%$ in $\mathrm{N}, 67 \%$ in $\mathrm{P}, 78 \%$ in $\mathrm{K}, 77 \%$ in $\mathrm{Ca}$, and $87 \%$ in $\mathrm{Mg}$ of nutritional determinations of pepper leaves.

Table 3. Comparative study of general ranges DRIS delivered optimum foliar nutrient concentration ranges for pepper with published sufficiency ranges $\left(\mathrm{mg} \mathrm{g}^{-1} \mathrm{DW}\right)$.

\begin{tabular}{lccccc}
\hline & $\mathbf{N}$ & $\mathbf{P}$ & $\mathbf{K}$ & $\mathbf{C a}$ & $\mathbf{M g}$ \\
\hline DRIS sufficiency & $34-56$ & $1.9-4.3$ & $30-51$ & $12-33$ & $4-15$ \\
Guzmán [21] & $36-37$ & $3.2-3.5$ & $31-33$ & $31-33$ & $5.6-6.1$ \\
Casas and Casas [22] & $33-50$ & $3.0-6.0$ & $45-55$ & $15-35$ & $7.5-13$ \\
Benton et al. [23] & $35-50$ & $1.8-7.0$ & $30-45$ & $10-28$ & $2.6-10.1$ \\
\hline
\end{tabular}

The sufficiency ranges of the different growth stages of pepper plant showed a normal distribution in all the data (Table 4). The optimal ranges delivered by DRIS technique showed the lowest ranges for N, P, and $\mathrm{K}$ in harvesting and the highest in FL. On the contrary, $\mathrm{Ca}$ and $\mathrm{Mg}$ showed the lowest range in FL and the highest in HV. Considering these sufficiency ranges, from 68 to $94 \%$ of pepper leaves samples were sufficient in all the growth stages. Comparing Tables 3 and 4, it can be observed that sometimes the nutrients can be slightly above or below the optimal range, and it is also noteworthy that in some of the cases the optimal ranges established for each phenological stage were more restrictive than the ranges reported for all stages of plant development.

Table 4. Comparative study of DRIS delivered for optimum foliar nutrient concentration ranges in different phenological stages for pepper with published sufficiency ranges $\left(\mathrm{mg} \mathrm{g}^{-1} \mathrm{DW}\right)$. Flowering (FL), fruiting (FT), fruit development (FD), and harvesting (HV).

\begin{tabular}{rlccccc}
\hline & $\mathbf{N}$ & $\mathbf{P}$ & $\mathbf{K}$ & $\mathbf{C a}$ & $\mathbf{M g}$ \\
\hline \multirow{3}{*}{ FL } & DRIS sufficiency & $47-64$ & $2.2-4.4$ & $38-55$ & $8-21$ & $4-10$ \\
& Cadahia [10] & $54-67$ & $1.5-5.0$ & $33-48$ & $12-23$ & $6-14$ \\
& Maynard and Hochmuth [24] & $30-50$ & $3-5$ & $25-50$ & $9-15$ & $3-5$ \\
\hline \multirow{3}{*}{ FT } & DRIS sufficiency & $45-53$ & $2.5-4.6$ & $34-53$ & $9-18$ & $5-10$ \\
& Cadahia [10] & $50-57$ & $2.1-4.0$ & $31-50$ & $14-24$ & $7-11$ \\
& Maynard and Hochmuth [24] & & & & & \\
\hline \multirow{3}{*}{ FD } & DRIS sufficiency & $41-52$ & $1.6-4.1$ & $20-57$ & $9-25$ & $4-13$ \\
& Cadahia [10] & $44-52$ & $2-4$ & $20-49$ & $17-30$ & $6-11$ \\
& Maynard and Hochmuth [24] & $29-40$ & $2.5-4.0$ & $25-40$ & $10-15$ & $3-4$ \\
\hline \multirow{3}{*}{ HV } & DRIS sufficiency & $28-40$ & $2.0-3.6$ & $17-40$ & $20-44$ & $7-19$ \\
& Cadahia [10] & $29-37$ & $1.6-3.0$ & $21-40$ & $29-42$ & $8-19$ \\
& Maynard and Hochmuth [24] & $25-30$ & $2-4$ & $20-30$ & $10-15$ & $3.0-4.0$ \\
\hline
\end{tabular}

\section{Discussion}

The norms derived from this experiment have a huge database with different types of soil and cultivars that generate a representative population variability as proposed by Llanderal et al. [5]. To reduce the high variability of the population or coefficient of variation sampled, DRIS norms were readjusted following the protocol reported by Caront and Parent [25] and Llanderal et al. [5] based on the development of DRIS norms in the different phenological stages.

The main conditions of variability in DRIS norms between samples in the sample period can be ascribed to varietal ability to uptake and use nutrients [26], climatic factor and the nutrient concentration in the fertigation [27], photosynthetic irradiance and root-zone temperature [28].

The importance of the lower value of CV in the DRIS norms means that there are huge changes in the nutritional balance of one crop with only slight modifications in a nutrient 
concentration [5] and this effect is more accentuated if the nutrient has been computed in several ratios [29].

Comparing the range of the CV in the different phenological stages, the FL showed the lowest range being in accordance with the data reported by Caront and Parent [25] and Llanderal et al. [5] with CV ranges from 8.5 to 19.5 and 8 to $15 \%$, respectively, in a tomato crop. This fact can be explained because flowering is a critical stage in plant development affecting mainly the harvesting index, therefore, small nutrient variations may result in yield detriments [5].

In this experiment, the phenological stages of FL showed ratios with lower CV such as N/P and N/K (26.44 and 19.22\%, respectively). Analogously, similar CV values for these ratios were reported by Abd El-Rheem et al. [15] (24.52 and 18.62\%, respectively) and Sánchez et al. [11] (20.04 and 9.98\%, respectively) in pepper crop. The importance of the N/P ratio may be because both elements have synergistic effects resulting in growth stimulation and enhanced uptake of both elements [20] and the importance of N/K ratio can be due to the increase of these nutrients requirements in fruiting [30] and consequently, any deficit of an element can have a negative impact on the growth and yield of pepper [31].

In this experiment, the phenological stage of fruiting (FT) had higher values of $\mathrm{CV}$ in the different nutrient ratios assessed, in agreement with the results reported by Llanderal et al. [5] in a tomato crop. Nevertheless, in fruit development (FD), there were two ratios with lower CV: N/P (30.34\%) and Ca/N (24.85\%). Similar results were also noted by Abd El-Rheem et al. [15] (P/N; 23.88\%) and Sánchez et al. [11] (Ca/N; 25.62\%) in pepper crop. The importance of N/P in the FD can be due to the high mobility translocation of both elements from leaf to the most nutrient demanding organs (fruits) [32,33]. No references in the literature about the relationship between $\mathrm{Ca}$ and $\mathrm{N}$ nutrients were found, but it is necessary to mention that both elements are essential in yield pepper [30], especially $\mathrm{Ca}$ which is one of the most demanded nutrients in fruit development and any deficiency may result in loss of yield [34]. In the last phenological stage, HV showed only a ratio with a lower $\mathrm{CV}(\mathrm{N} / \mathrm{P} ; 23.58 \%)$. The importance of this ratio in $\mathrm{HV}$ can be related to the high uptake of both elements due to the high metabolic fruit requirements [35]. Finally, in relation to the lowest $\mathrm{CV}$ in the DRIS norms, $\mathrm{N}$ appears in all the ratios with the lowest $\mathrm{CV}$ showing that this nutrient is critical in pepper yield.

The general sufficiency ranges generated by DRIS norms were compared with other researchers [21-23] (Table 3). In our experiment, the $\mathrm{N}$ sufficiency range calculated was similar with the data reported by the previous authors. In the case of $\mathrm{P}$, our ranges were lower compared to the data reported by Guzmán [21], Casas and Casas [22] and Benton et al. [23]. This lowest value in the sufficiency range of $P$ can be ascribed to the low uptake of this element especially under low temperatures such as what happened in the experimental period of this work (autumn-winter) [36]. With respect to the other nutrients such as $\mathrm{K}, \mathrm{Ca}$ and $\mathrm{Mg}$, our data were similar with the results compared with the other researchers [21-23].

The sufficiency ranges established in each phenological stage after the DRIS method were also compared with other researchers $[10,24]$ (Table 4). These sufficiency ranges were similar to that proposed by Maynard and Hochmuth [24] and Cadahia [10] except for the case of $\mathrm{Ca}$ and $\mathrm{Mg}$ which were higher in all the phenological stages compared to the ranges proposed by Maynard and Hochmuth [24]. This fact can be associated to the high concentration of both elements in the chemical composition of the soil area grown as reported by Lao [37]. The comparison of sufficiency ranges for N, P and K in harvesting with respect to the other phenological stages noted a clear decrease which can be ascribed to the dilution factor [8]. In the same vein, the comparison of sufficiency ranges between different phenological stages reported a higher concentration of $\mathrm{Ca}$ and $\mathrm{Mg}$ in harvesting which related to the accumulation of both elements in the leaf throughout the crop due to their low mobility [32]. This variability of sufficiency ranges in the phenological stages can be due to the uptake and use of nutrients [26]; climatic factor and the nutrient concentration 
in the fertigation [27]; photosynthetic irradiance and root-zone temperature [28], as happens with the DRIS norms.

\section{Conclusions}

In conclusion, DRIS norms and sufficiency ranges for pepper proposed in this experiment were sensitive to phenological stages being of special importance the role of $\mathrm{N}$ in crop yield as a consequence of the low CV reported in the different ratios assessed. From an agronomical point of view, these results highlight firstly the importance of an adequate supply of nitrogen in pepper yield and secondly can be used as a nutritional reference between growers of the same species under similar climatic conditions or production systems.

Author Contributions: A.L. investigation, data curation, writing-original draft preparation. P.G.-C. writing—review and editing, M.T.L. writing-review and editing, M.L.S. conceptualization, supervision, project administration. All authors have read and agreed to the published version of the manuscript.

Funding: This research received no external funding.

Institutional Review Board Statement: Not applicable.

Informed Consent Statement: Not applicable.

Data Availability Statement: Not applicable.

Acknowledgments: Institute of Research and Training in Agriculture and Fishery (IFAPA), Junta of Andalusia for its contribution to the leaf analysis database.

Conflicts of Interest: The authors declare no conflict of interest.

\section{References}

1. Cajamar, F. Análisis de la campaña hortofrutícola de Almería 2019/2020. In Informes y Monografías; Caja Rural Almeria: Almeria, Spain, 2021; p. 9.

2. Valera, D.M.; Belmonte, L.; Molina, F.D.; Lopez, A. Greenhouse Agriculture in Almería: A Comprehensive Techno-Economic Análisis; Cajamar Caja Rural: Almería, Spain, 2016; p. 408.

3. Hallmark, W.B.; Beverly, R.B. Review: An update in the use of the diagnosis and recommendation integrated system. J. Fer. 1991, $8,74-88$.

4. Llanderal, A. Study of Diagnostic Methods and Evaluation of Nutritional Parameters in the Intensive Horticulture Cropping Systems as Basis for a Sustainable Management of the Fertigation. Ph.D. Thesis, Universidad de Almería, Almeria, Spain, September 2017; p. 197.

5. Llanderal, A.; Lao, M.T.; Contreras, J.I.; Segura, M.L. Diagnosis and recommendation integrated system norms and sufficiency ranges for tomato greenhouse in Mediterranean climate. HortScience 2018, 53, 479-482. [CrossRef]

6. Ali, A.M. Nutrient sufficiency ranges in mango using boundary-line approach and compositional nutrient diagnosis norms in El-Salhiya, Egypt. Comm. Soil Sci. Plant Anal. 2018, 49, 188-201. [CrossRef]

7. Sumner, M.E. Interpretation of foliar analysis for diagnostic purposes. Agron. J. 1979, 71, 343-348. [CrossRef]

8. Marschner, H. Mineral Nutrition of Higher Plants, 3nd ed.; Academic Press: Cambridge, MA, USA, $2011 ;$ p. 672.

9. Hochmuth, G.; Maynard, D.; Vavrina, C.; Hanlon, E. Plnt Tissue Analysis and Interpretation for Vegetable Crops in Florida; Florida Coop. Ext. Spec. Ser. SS-VEC-42; University of Florida: Gainesville, FL, USA, 1991.

10. Cadahía, C. La Savia Como Índice De Fertilización. Cultivos Agroenergéticos, Hortícolas, Frutales Y Ornamentales; Mundi-Prensa: Madrid, Spain, 2008; p. 256.

11. Sánchez, E.; Soto-Parra, J.M.; Preciado-Rangel, P.; Llanderal, A.; Lao, M.T. DRIS Norms for grafted and non-grafted red bell pepper in semiarid climate conditions in a greenhouse. Hortic. Bras. 2018, 36, 371-376. [CrossRef]

12. Beaufils, E.R. Physiological diagnosis: A guide for improving maize production based on principles developed for rubber trees. Fert. Soc. S. Afr. J. 1971, 1, 1-28.

13. Walworth, J.L.; Sumner, M.E. The diagnosis and recommendation integrated system (DRIS). Adv. Soil Sci. 1987, 6, 149-188.

14. Nick, J.A. DRIS for Coffee Plants; USP/ESALQ: Piracicaba, Brazil, 1998. (In Portuguese)

15. El-Rheem, K.M.A.; Khaled, S.M.; Zaghoul, S.M. Preliminary DRIS norms for evaluating the nutritional statue of sweet pepper crop. Aust. J. Basic Appl. Sci. 2012, 6, 661-664.

16. Hernando, V.; Cadahía, C. El Análisis De Savia Como Índice De Fertilización; CSIC, Instituto de Edafología y Biología Vegetal: Madrid, Spain, 1973.

17. MAPA. Métodos Oficiales de Análisis; Tomo III; Secretaría General Técnica del Ministerios de Agricultura, Pesca y Alimentación: Madrid, Spain, 1986. 
18. Ma, T.; Zuazaga, G. Micro-Kjeldahl Determination of Nitrogen. A new indicator and an improved rapid method. Ind. Eng. Chem. Anal. Ed. 1942, 14, 280-282. [CrossRef]

19. Bhargava, B.S. Leaf analysis for nutrient diagnosis, recommendation and management in fruit crops. J. Ind. Soc. Soil Sci. 2002, 50, 352-373.

20. García-Caparrós, P.; Llanderal, A.; Majsztrik, J.; Maksimovic, I.; Lao, M.T. Preliminary nutrient diagnosis norms and optimum ranges in potted ornamental plants grown under saline conditions. J. Plant Nutr. 2019, 42, 2805-2813. [CrossRef]

21. Guzman, J.M. Nutritional Balance in Greenhouse Conditions: Correction and Improvement of Harvesting. Ph.D. Thesis, University of Granada, Granada, Spain, 1987. (In Spanish)

22. Casas, A.; Casas, E. Soil-Water-Plant Analysis and Their Application in the Nutrition of Horticultural Crops in the Southeastern of Almeria; Caja Rural Almeria: Almeria, Spain, 1999.

23. Benton Jones, J.J.; Wolf, B.; Mills, H.A. Plant Analysis Handbook; MicroMacro Publishing, Inc.: Athens, GA, USA, $1991 ;$ p. 213.

24. Maynard, D.N.; Hochmuth, G.J. Knott's Handbook for Vegetable Growers, 5th ed.; John Wiley \& Sons, Inc.: New York, NY, USA, 2007.

25. Caront, J.; Parent, L.E. Derivation and assessment of DRIS norms for greenhouse tomatoes. Can. J. Plant Sci. 1989, 69, 1027-1035. [CrossRef]

26. English, J.E.; Barker, A.V. Ion interactions in Ca-efficient and Ca-inefficient tomato lines. J. Plant Nutr. 1987, 10, 857-869. [CrossRef]

27. Segura, M.L.; Contreras, J.I.; Salinas, R.; Lao, M.T. Influence of salinity and fertilization level on greenhouse tomato yield and quality. Commun. Soil Sci. Plant Anal. 2009, 40, 485-497. [CrossRef]

28. Tremblay, N.; Gasia, M.C.; Ferauge, M.T.; Gosselin, A.; Trudel, M.J. Influence of photosynthetic irradiance on nitrate reductase activity, nutrient uptake and partitioning in tomato plants. J. Plant Nutr. 1988, 11, 17-36. [CrossRef]

29. Hermida, J.J.F.; Toro, M.C.H.; Guzman, M.; Cabrera, R.I. Determining nutrient diagnostic norms for greenhouse roses. HortScience 2013, 48, 1403-1410. [CrossRef]

30. Noh-Medina, J.; Borges-Gómez, L.; Soria-Fregoso, M. Composición nutrimental de biomasa y tejidos conductores en chile habanero (Capsicum chinense Jacq.). Trop. Subtro. Agroeco. 2010, 12, 219-228.

31. Contreras, J.I.; Galindo, P.; Catala, J.J.; Segura, M.L. Response of greenhouse pepper crop to fertilizer levels and different qualities of irrigation water. Acta Hortic. 2006, 203-206. [CrossRef]

32. Llanderal, A.; García-Caparrós, P.; Contreras, J.I.; Segura, M.L.; Teresa Lao, M. Testing foliar nutritional changes in space and over time in greenhouse tomato. J. Plant Nutr. 2019, 42, 333-343. [CrossRef]

33. Llanderal, A.; García-Caparrós, P.; Pérez-Alonso, J.; Contreras, J.I.; Segura, M.L.; Reca, J.; Lao, M.T. Approach to petiole sap nutritional diagnosis method by empirical model based on climatic and growth parameters. Agronomy 2020, 10, 188. [CrossRef]

34. Marti, H.R.; Mills, H.A. Calcium uptake and concentration in bell pepper plants as influenced by nitrogen form and stages of development. J. Plant Nutr. 1991, 14, 1177-1185. [CrossRef]

35. Betancourt, P.; Pierre, F. Extracción de macronutrientes por el cultivo de tomate (Solanum lycopersicum Mill. var. "Alba") en casas de cultivo en Quíbor, estado Lara. Bioagro 2013, 25, 181-188.

36. Fernández, M.T. Fósforo: Amigo o enemigo. ICIDCA. Sobre Los Deriv. De La Caña De Azúcar 2007, 41, 51-57.

37. Lao, M.T. Fertigation Management in the Greenhouses from Almeria by Means of Suction Cups. Ph.D. Thesis, University of Almería, Almería, Spain, 2002. (In Spanish) 